\title{
Termination of Cryogenian ironstone deposition by deep ocean euxinia
}

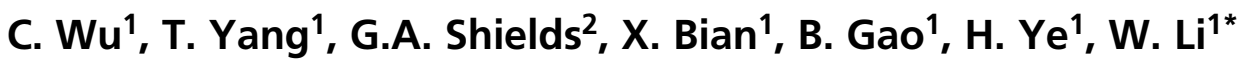

Abstract

doi: 10.7185/geochemlet.2025

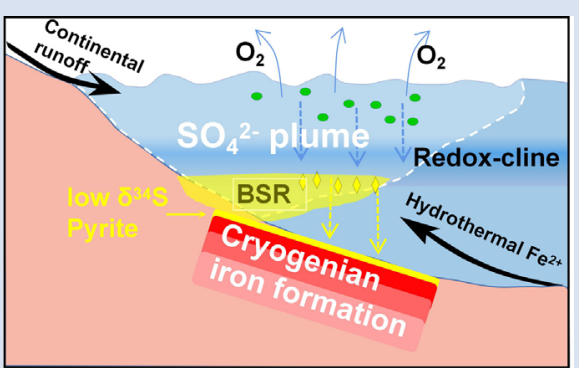

Widespread deposition of iron-rich sedimentary rocks (ironstones) occurred during the Sturtian ice age, the earlier of two Cryogenian 'Snowball Earth' glaciations. However, the reasons for the termination of Cryogenian Iron Formation (CIF) deposition remain poorly understood. Here we report a multi-isotope (Fe-C-S) study of the Xinyu CIF in South China that can directly address this question. The isotopic compositions of these multivalent elements exhibit remarkable covariance at the top of the Xinyu CIF that reflects progressive redox stratification during iron oxide deposition. Iron oxide deposition ended abruptly due to the titration of ferrous iron as pyrite following a large influx of riverine sulfate. Although termination of CIF deposition is commonly attributed to oxygenation, our data show that at least in some Cryogenian ocean basins, CIF deposition ended with the spread of euxinic rather than oxygenated waters.

Received 15 March 2020 | Accepted 4 June 2020 | Published 23 July 2020

\section{Introduction}

The Cryogenian Period (ca. 720-635 Ma) marks a turning point in the history of Earth's surficial environment, when seawater changed from a generally anoxic, ferruginous and sulfate-poor state (Canfield et al., 2008; Guilbaud et al., 2015) to a more oxygenated, Fe-poor and sulfate-rich state (Sahoo et al., 2012; Shields et al., 2019) that progressively came to dominate through the ensuing Phanerozoic Eon (Och and ShieldsZhou, 2012). Iron formations were deposited globally during the Cryogenian Period, following an interval of over 1 billion years, during which iron formations were rare (Cox et al., 2013; Hoffman et al., 2017), but not entirely absent (Canfield et al., 2018). Iron formation deposition requires a reduced ocean to allow effective transport of iron in its soluble form, $\mathrm{Fe}^{2+}$, as well as a mechanism for oxidation of the $\mathrm{Fe}^{2+}$ and accumulation of large masses of Fe oxides/hydroxides. Reappearance of widespread iron deposits during the Cryogenian Period has been taken, therefore, as supporting evidence for the "Snowball Earth" hypothesis, as global ice sheet cover could have led to widespread ocean anoxia (Hoffman and Schrag, 2002; Kirschvink, 1992). The appearance of Cryogenian iron formations (CIFs) provides robust evidence for the return of Fe(II)rich, anoxic oceans, and by the same token, termination of CIF deposition was likely linked to some fundamental change in ocean chemistry.

Was disappearance of the CIFs caused by a decrease in $\mathrm{Fe}^{2+}$ concentration due to ocean oxygenation as seen in modern oceans? Or was it caused by the depletion of free oxygen and development of euxinic $\left(\mathrm{H}_{2} \mathrm{~S}\right.$-rich) environments as has been proposed for the Mesoproterozoic (Canfield, 1998) and Ediacaran oceans (Li et al., 2010)? The details of CIF termination bear on our understanding of the chemistry of Cryogenian oceans, and are critical for a better understanding of the biological radiations and diversification that followed. However, the termination of CIF deposition, its cause and related environmental implications, have been little discussed to date (Cox et al., 2013). Iron, carbon and sulfur are major players in natural redox processes and show significant isotopic differences between their reduced and oxidised forms. In this study, we present an integrated study of C-S-Fe isotope data from a new drill core record for a large Sturtian-aged CIF from South China that was deposited in a deep marine setting. The completeness of the drill core record is unprecedented for Cryogenian iron formations and the isotopic signatures hold clues about the onset, development, and particularly, termination of CIF deposition.

\section{Clues from a Deep Water Cryogenian Iron Formation}

The CIF from Xinyu, Jiangxi Province, China presents a remarkable opportunity to study ocean chemistry during the Cryogenian glaciation (Tang et al., 1987; Zhu et al., 2019). The southern margin of the Yangtze Craton of South China hosts a number of stratigraphically correlative CIFs that are associated with successions assigned to the $\sim 55 \mathrm{Myr}$, early Cryogenian 'Sturtian' ice age (Figs. 1, S-1). The Xinyu CIF, which is the largest among the South China deposits, was deposited offshore

\footnotetext{
State Key Laboratory for Mineral Deposits Research, School of Earth Sciences and Engineering, Nanjing University, Nanjing, Jiangsu 210023, PR China

Department of Earth Sciences, University College London, Gower Street, London WC1E 6BT, UK

Corresponding author (email: liweiqiang@nju.edu.cn)
} 

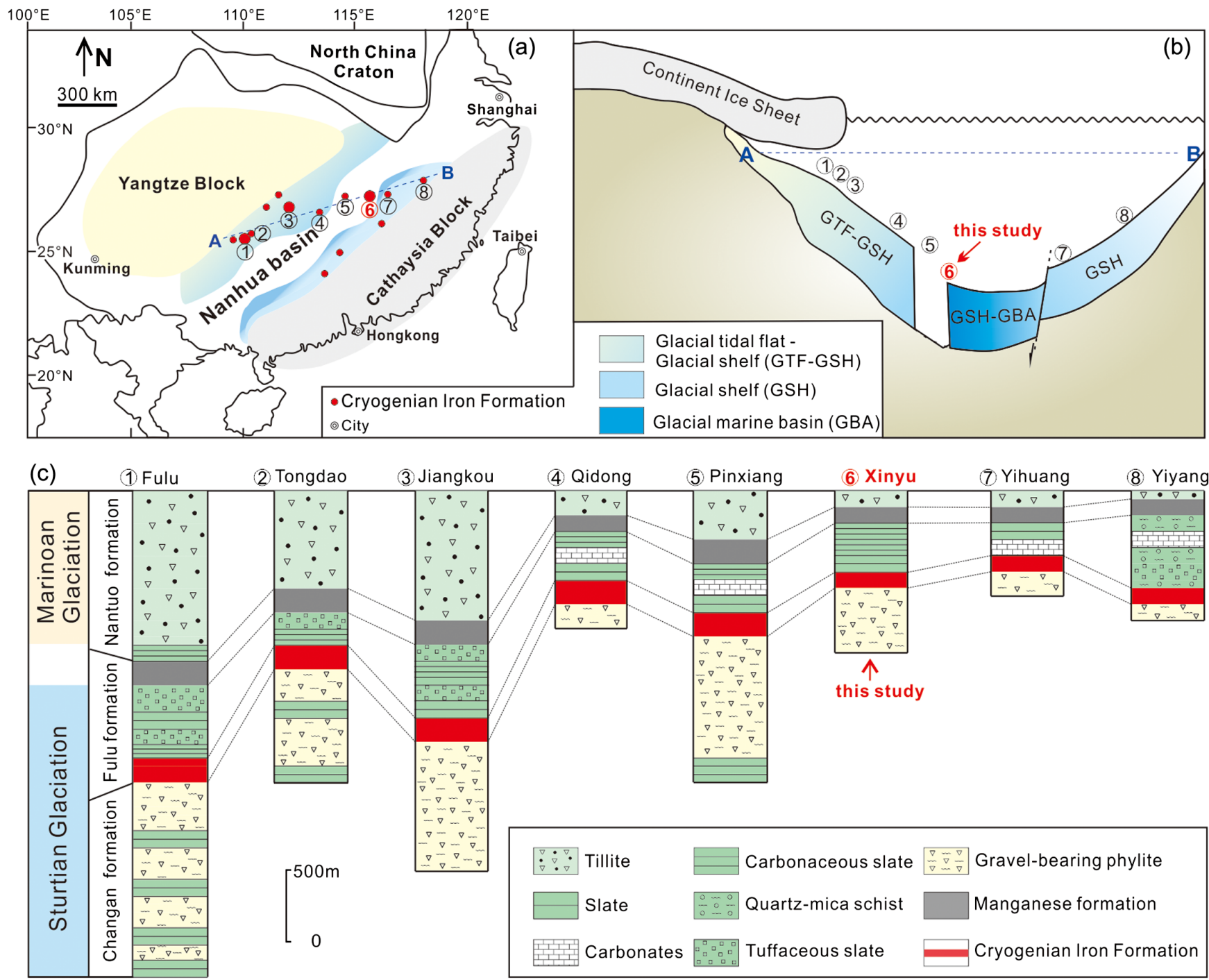

Figure 1 (a) Distribution of Cryogenian Iron Formations in South China and their tectonic setting during the Neoproterozoic. (b) Tectonic background and palaeo-depth of the Cryogenian iron formations, after Wang and Li (2003). (c) Stratigraphic correlations of different CIFs from South China, after Tang et al. (1987). The thickness of iron formations, manganese formations, and carbonate in between are magnified for illustration, and do not represent true thickness.

within the Nanhua rift basin that separated the Yangtze Craton and the Cathaysia Block during the Neoproterozoic Era. It was deposited in deep water (Wang and Li, 2003), and contains magnetite as the major Fe oxide mineral. The Xinyu CIF is uniform in its stratigraphic sequence and can be traced continuously for over $60 \mathrm{~km}$ (Fig. S-2), despite local deformation and greenschist facies metamorphism. The Xinyu CIF in the ore district is underlain by a magnetite-bearing, chlorite-sericite phyllite and overlain by a pyrite-bearing sericite phyllite (Figs. 2, S-3). The pyrite-bearing phyllite horizon is used as a faithful marker for the termination of Xinyu CIF by the local iron ore exploration geologists. Magnetite and pyrite in the sericite phyllite are generally disseminated and euhedral to subhedral in shape (Figs. S-4 to S-6). These rocks also contain platy hematite and irregular interstitial carbonates (mostly ankerite) as minor constituents (Figs. S-7, S-8). The lack of overgrowth texture in magnetite and occurrence of minute Fe oxide inclusions in ankerite suggest that the two minerals were products of early diagenesis, rather than late metamorphic events (Figs. S-9, S-10).
We characterised the Fe isotope data of magnetite and pyrite, $\mathrm{S}$ isotope data of pyrite, and $\mathrm{C}$ isotope data of interstitial carbonates from a representative drill core that intersects the strata bearing the Xinyu CIF (Fig. 2). Details of analytical methods are provided in the Supplementary Information. The $\delta^{56} \mathrm{Fe}$ values cluster around a crustal baseline value of $+0.1 \%$ for disseminated magnetite grains in the chlorite-sericite phyllite (Fig. 2) underlying the Xinyu CIF, but values increase monotonically up-section within the Xinyu CIF, reaching a maximum value of $+2 \%$ at the top of the CIF. This trend is mirrored by the $C$ isotope values of interstitial carbonates $\left(\delta^{13} C_{\text {carb }}\right)$, which decrease from $-7 \%$ in the lower magnetite-bearing, chloritesericite phyllite to $-12 \%$ at the top of the Xinyu CIF. These $\delta^{13} \mathrm{C}_{\text {carb }}$ values abruptly increase to around $-8 \%$ across the boundary between CIF and the overlying sericite phyllite. This is echoed by a fundamental change in the mineralogy of the disseminated Fe-bearing minerals in the sericite phyllite, whereby magnetite changes to pyrite. The $\delta^{56} \mathrm{Fe}$ values of the pyrite grains scatter about $+0.5 \%$, whereas $\delta^{34} \mathrm{~S}$ values increase from a very low value of $-40 \%$ o to a high point of $+7 \%$, before returning to around $0 \%$ up-section (Fig. 2). 

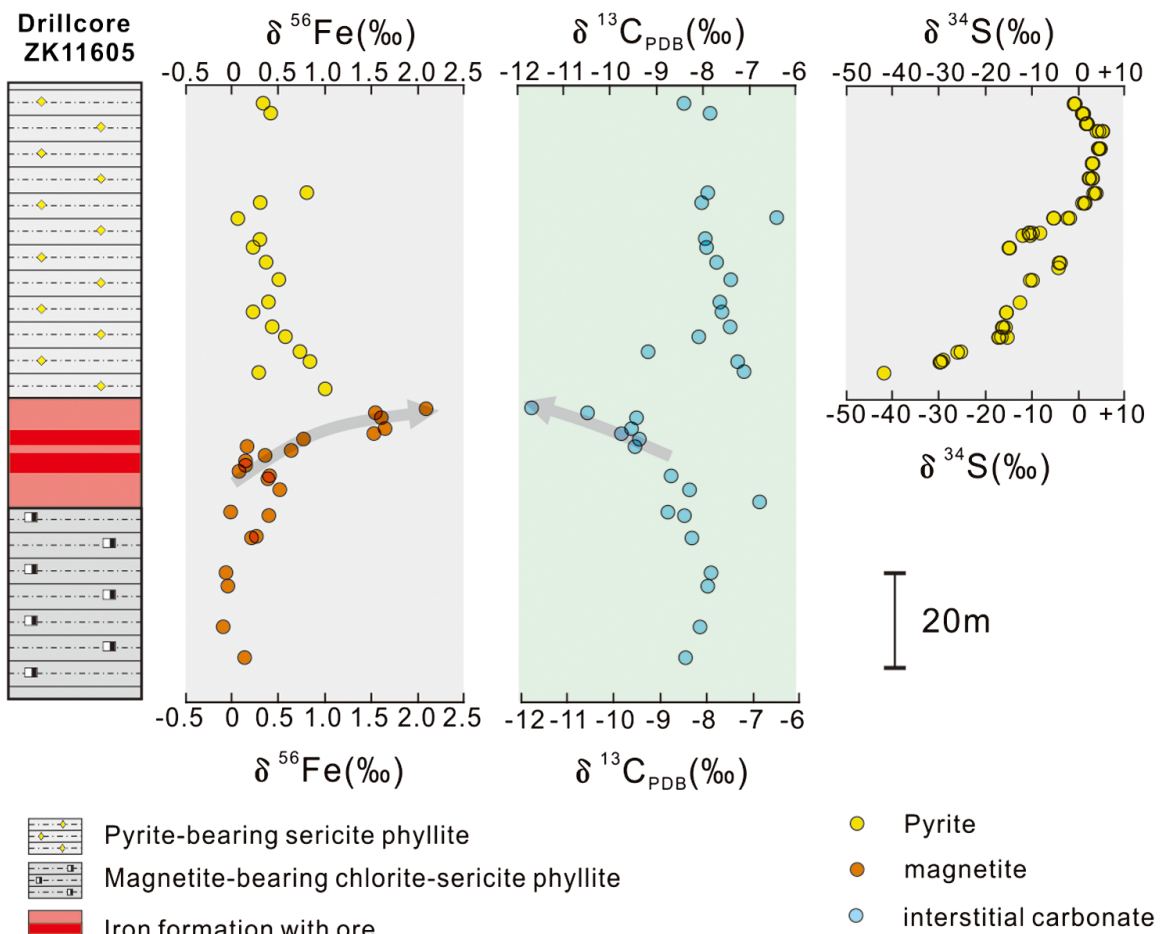

Figure 2 Stratigraphic column and Fe-C-S isotope data along a drill core of the Xinyu CIF.

\section{Discussion}

The upward trend towards higher $\delta^{56} \mathrm{Fe}$ values within the Xinyu $\mathrm{CIF}$ is similar to previously reported Fe isotope patterns from Xinyu and other 'Sturtian' CIFs worldwide (Zhu et al., 2019). The source of iron in the iron formations is believed to have been hydrothermal fluids that have $\delta^{56} \mathrm{Fe}$ values close to $0 \%$ or slightly lower (Johnson et al., 2008). The low $\delta^{56} \mathrm{Fe}$ values in the lower Xinyu CIF likely record periods of efficient oxidation and quantitative removal of hydrothermal Fe(II) that occurred during the early stages of CIF deposition (Fig. 3a). Given that the primary precipitates of $\mathrm{Fe}$ (II) oxidation (i.e. Fe(III) oxides/ hydroxides) enrich heavy $\mathrm{Fe}$ isotopes over aqueous $\mathrm{Fe}(\mathrm{II})$ by 3-4 \%o at equilibrium (Johnson et al., 2008), the positive $\delta^{56} \mathrm{Fe}$ values in iron formations are most parsimoniously explained by partial oxidation of hydrothermal Fe(II) (Johnson et al., 2008; Li et al., 2013). Increasing $\delta^{56} \mathrm{Fe}$ up-section in the CIFs, therefore, reflects a decreasing availability of free $\mathrm{O}_{2}$ to oxidise Fe(II) $)_{\mathrm{aq}}$ in the Cryogenian oceans (Fig. 3b). Decreased $\mathrm{O}_{2}$ production seems unlikely in deglacial oceans, as removal of ice sheets would have allowed photosynthetic organisms to thrive, and moreover, newly resumed global hydrological cycles would have delivered abundant nutrient elements (e.g., P) into the oceans to boost biological productivity (Shields et al., 1997; Och and Shields-Zhou, 2012). Therefore, development of a redoxcline and decrease in oxidation efficiency (i.e. increase in partial oxidation) of deep water Fe(II) seems a more plausible explanation for the Fe isotope trend recorded in the Xinyu CIF (Fig. 3b).

Concomitant with the up-section increase in magnetite $\delta^{56} \mathrm{Fe}$, there is a decrease in $\delta^{13} \mathrm{C}_{\text {carb }}$ from mantle-like values of around $-8 \%$ in the sericite phyllite to values as low as $-12 \%$ at the top of the Xinyu CIF. Low $\delta^{13} \mathrm{C}_{\text {carb }}$ values in carbonates frequently reflect contributions from organic $\mathrm{C}$ that has significantly lower $\delta^{13} \mathrm{C}$ values than dissolved inorganic carbon. Dissimilatory iron reduction (DIR) by microbes in soft sediments has been identified as an effective mechanism that transforms
Fe(III) hydroxides into magnetite and remineralises organic carbon to form low $\delta^{13} \mathrm{C}$ diagenetic carbonates (Heimann et al., 2010; Craddock and Dauphas, 2011). The decreasing $\delta^{13} C_{\text {carb }}$ values within the Xinyu CIF could therefore reflect increasing delivery to the seafloor of organic matter and efficient remineralisation by DIR microbes. The activity of $\mathrm{O}_{2}$-respiring heterotrophic microbes in the water column in the presence of abundant organic matter supply would consume dissolved $\mathrm{O}_{2}$, producing mid-column anoxia, which lowered the intensity of aqueous $\mathrm{Fe}(\mathrm{II})$ oxidation, producing high $\delta^{56} \mathrm{Fe} \mathrm{Fe}(\mathrm{III})$ precipitates (Fig. $3 b$ ). Therefore, the $\mathrm{C}$ isotope record corroborates the Fe isotope evidence for a strengthening of redox stratification during precipitation of the upper part of the Xinyu CIF.

The termination of CIF deposition at Xinyu was immediately followed by deposition of rocks containing pyrite with very low $\left(-40 \%\right.$ o $\delta^{34} S$ values (Fig. 2). Deposition of pyrite requires $\mathrm{S}^{2-}$, which could be provided by microbial reduction of $\mathrm{SO}_{4}^{2-}$ in the presence of organic matter. It is widely accepted that sulfate was depleted in oceans during the Snowball Earth Events (Kump and Seyfried, 2005). Deglaciation, however, could have provided a source of sulfate via renewed riverine input from continents. The dissolved sulfate was delivered to oceans by rivers, but due to density differences, the sulfate likely spread initially within plumes of freshwater at the surface mixing zone, separated from the organic-rich water body and seafloor below the redoxcline (Fig. 3b). As soon as sulfate could reach beneath the redoxcline, microbes would have been capable of metabolising organic matter via the bacterial sulfate reduction pathway, releasing $\mathrm{H}_{2} \mathrm{~S}$ that reacted with hydrothermal $\mathrm{Fe}^{2+}$ to form low solubility Fe sulfide precipitates (Fig. 3c). Predominance of bacterial sulfate reduction therefore terminated the deposition of Fe(III) hydroxides in CIF.

The pyrite grains that precipitated immediately after the CIF have very low $(-40 \%) \delta^{34} S$ values. Experiments have shown that the magnitude of $\mathrm{S}$ isotope fractionation associated with bacterial sulfate reduction is controlled by the amount of sulfate, whereby the maximum $\Delta^{34} S_{\text {sulfate-sulfide }}$ fractionation 

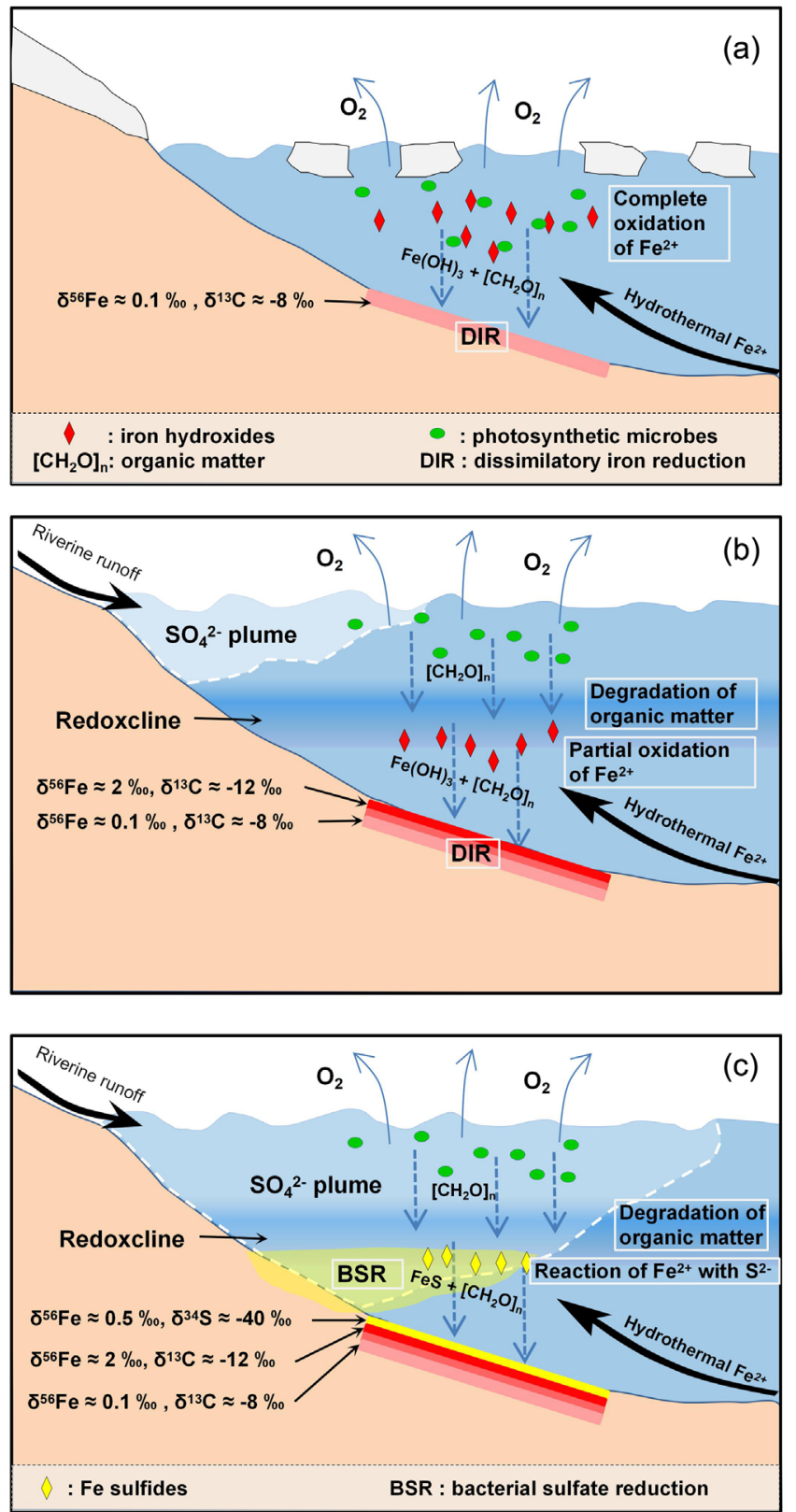

Figure 3 A conceptual model for initiation, development, and termination of Cryogenian iron formations.

factor of $\sim 45 \%$ o occurs in the presence of $>1 \mathrm{mM}$ sulfate in water (Habicht and Canfield, 1997). Therefore, the very low $\delta^{34} \mathrm{~S}$ signatures of pyrite require that bacterial sulfate reduction started with abundant $(>1 \mathrm{mM})$ dissolved sulfate. The onset of pyrite precipitation after CIF termination implies a rapid delivery of abundant sulfate to deeper oceans. The increase in pyrite $\delta^{34} \mathrm{~S}$ values implies that the consumption of dissolved sulfate by bacterial sulfate reduction outpaced replenishment of sulfate from rivers, leading to a decrease in the global ocean sulfate reservoir, and progressively higher $\delta^{34} \mathrm{~S}$ in residual sulfate.

The Fe-C-S isotope record presents a compelling case for termination of CIF deposition by sulfur cycling and extensive development of euxinia in the water column of deglacial Cryogenian oceans. It has been proposed that the termination of major banded iron formations around $1.8 \mathrm{Ga}$ was caused by the development of euxinic oceans (Poulton et al., 2004). Deposition of pyrite-bearing sediments following ironstone deposition has not been reported from CIF sequences in other parts of the world, so it is possible that the Xinyu CIF is a special case that is different from other CIFs in terms of the pathway of IF termination. This can be explained by the differences in the depth of IF deposition. Xinyu CIF was deposited in a deep marine setting based on sedimentary facies analysis (Tang et al., 1987) and palaeogeographic reconstruction (Wang and Li, 2003), therefore the spread of ocean euxinia is recorded by the deep Xinyu CIF, but not in other shallow CIFs as Fe(II) delivery was cut in deeper seawater. A recent study reported widespread euxinia at the end of Marinoan glaciation, whereby the abundance of pyrite nodules was significantly greater in deep settings than in shallow settings (Lang et al., 2018). We therefore argue that the spread of euxinia into deep oceans and titration of hydrothermal $\mathrm{Fe}^{2+}$ by sulfides is a viable mechanism to explain the disappearance of IFs after the Cryogenian Period. If so, the mineralogical and isotopic records of the Xinyu CIF pinpoint the onset of euxinia, which was to be become widespread along productive margins until the Cambrian (Li et al., 2010). Isotopic records from the Xinyu CIF also testify to the diversity and prosperity of the ocean microbial community. A microbial ecosystem of diverse metabolisms, including oxygenic photosynthesis, $\mathrm{O}_{2}$-respiring heterotrophism, DIR, and BSR thrived through cycling of redox elements (O-C-S-Fe) in Cryogenian oceans upon deglaciation.

\section{Acknowledgements}

This manuscript benefited from constructive comments from two anonymous reviewers, as well as editorial comments from Dr. Sophie Opfergelt. The authors thank Tianyu Chen and Xuelei Chu for discussions. This study is supported by the Strategic Priority Research Program (B) of the Chinese Academy of Sciences (XDB26020101) to WL, National Key R\&D Program of China (Grant No. 2018YFC0603703) to CZW, and Natural Science Foundation of China (No. 41622301 to WL and No. 41872077 to CZW).

Editor: Eric H. Oelkers

\section{Additional Information}

Supplementary Information accompanies this letter at http:// www.geochemicalperspectivesletters.org/article2025.



(C) 2020 The Authors. This work is distributed under the Creative Commons Attribution NonCommercial No-Derivatives 4.0 License, which permits unrestricted distribution provided the original author and source are credited. The material may not be adapted (remixed, transformed or built upon) or used for commercial purposes without written permission from the author. Additional information is available at http://www. geochemicalperspectivesletters.org/copyright-and-permissions.

Cite this letter as: $\mathrm{Wu}, \mathrm{C} .$, Yang, T., Shields, G.A., Bian, X., Gao, B., Ye, H., Li, W. (2020) Termination of Cryogenian ironstone deposition by deep ocean euxinia. Geochem. Persp. Let. $15,1-5$.

\section{References}

CANFIELD, D.E. (1998) A new model for Proterozoic ocean chemistry. Nature 396, 450-453.

Canfield, D.E., Poulton, S.W., Knoll, A.H., Narbonne, G.M., Ross, G., Goldberg, T., Strauss, H. (2008) Ferruginous Conditions Dominated Later Neoproterozoic Deep-Water Chemistry. Science 321, 949. 
Canfield, D.E., Zhang, S., Wang, H., Wang, X., Zhao, W., Su, J., BJerrum, C.J Haxen, E.R., and Hammarlund, E.U., Hammarlund, E.U. (2018) A Mesoproterozoic iron formation. Proceedings of the National Academy of Sciences 115, E3895.

Cox, G.M., Halverson, G.P. Minarik, W.G, Le Heron, D P. Macdonald, F.A Bellefroid, E.J., Strauss, J.V. (2013) Neoproterozoic iron formation: An evaluation of its temporal, environmental and tectonic significance. Chemical Geology 362, 232-249.

CRADDOCK, P.R., DAUPHAS, N. (2011) Iron and carbon isotope evidence for microbial iron respiration throughout the Archean. Earth and Planetary Science Letters 303, 121-132.

Guilbaud, R., Poulton, S.W., Butterfield, N.J., Zhu, M., Shields-Zhou, G.A. (2015) A global transition to ferruginous conditions in the early Neoproterozoic oceans. Nature Geoscience 8, 466-470.

Habicht, K.S., CANFIELD, D.E. (1997) Sulfur isotope fractionation during bacterial sulfate reduction in organic-rich sediments. Geochimica et Cosmochimica Acta 61, 5351-5361.

Heimann, A., Johnson, C.M., Beard, B.L., Valley, J.W., Roden, E.E., Spicuzza, M.J, BeuKes, N.J. (2010) Fe, C, and O isotope compositions of banded iron formation carbonates demonstrate a major role for dissimilatory iron reduction in $\sim 2.5$ Ga marine environments. Earth and Planetary Science Letters 294, 8-18.

Hoffman, P.F., Schrag, D.P. (2002) The snowball Earth hypothesis: testing the limits of global change. Terra Nova 14, 129-155.

Hoffman, P.F., Aвbot, D.S., Ashrenazy, Y., Benn, D.I., Brocks, J.J., Cohen, P.A Cox, G.M., Creveling, J.R., Donnadieu, Y., Erwin, D.H., et al. (2017) Snowball Earth climate dynamics and Cryogenian geology-geobiology. Science Advances 3, e1600983.

Johnson, C.M., Beard, B.L., Roden, E.E. (2008) The Iron Isotope Fingerprints of Redox and Biogeochemical Cycling in Modern and Ancient Earth. Annual Review of Earth and Planetary Sciences 36, 457-493.

KIRSCHVINK, J.L. (1992) Late Proterozoic low-latitude global glaciation: The snowball Earth. In: SchOPf, J.W., KLeIN, C. (Eds.) Cambridge University Press, Cambridge.

KumP, L.R., SEYFRIED, W.E. (2005) Hydrothermal Fe fluxes during the Precambrian: Effect of low oceanic sulfate concentrations and low hydrostatic pressure on the composition of black smokers. Earth and Planetary Science Letters $235,654-662$.

Lang, X., Shen, B., Peng, Y., XiaO, S., Zhou, C., Bao, H., Kaufman, A.J., Huang, K., Crockford, P. W., Liv, Y., et al., (2018) Transient marine euxinia at the end of the terminal Cryogenian glaciation. Nature Communications 9, 3019

LI, C., Love, G.D., Lyons, T.W., Fike, D.A., Sessions, A.L., Chu, X. (2010) A Stratified Redox Model for the Ediacaran Ocean. Science 328, 80.

Li, W., Czaja, A.D., Van Kranendonk, M.J., Beard, B.L., Roden, E.E., Johnson, C.M. (2013) An anoxic, Fe(II)-rich, U-poor ocean 3.46 billion years ago. Geochimica et Cosmochimica Acta 120, 65-79.

Och, L.M., Shields-Zhou, G.A. (2012) The Neoproterozoic oxygenation event: Environmental perturbations and biogeochemical cycling. Earth-Science Reviews 110, 26-57.

Poulton, S.W., Fralick, P.W., Canfield, D.E. (2004) The transition to a sulphidic ocean $\sim 1.84$ billion years ago. Nature 431, 173-177.

Sahoo, S.K., Planavsky, N.J., Kendall, B., Wang, X., Shi, X., Scott, C, Anbar, A.D., LYONS, T.W., JiAnG, G. (2012) Ocean oxygenation in the wake of the Marinoan glaciation. Nature 489, 546-549.

Shiflds, G., Stille, P., Brasier, M.D., Atudorei, N. (1997) Stratified oceans and oxygenation of the late Precambrian environment: a post glacial geochemical record from the Neoproterozoic of W. Mongolia. Terra Nova 9, 218-222.

Shields, G.A., Mills, B.J.W., Zhu, M., Raub, T.D., Daines, S.J., Lenton, T.M. (2019) Unique Neoproterozoic carbon isotope excursions sustained by coupled evaporite dissolution and pyrite burial. Nature Geoscience 12, 823-827.

TANG, J., Fu, H., YU, Z. (1987) Stratigraphy, type and formation conditions of the late precambrian banded iron ores in south China. Chinese Journal of Geochemistry 6, 331-341.

WANG, J., LI, Z. (2003) History of Neoproterozoic rift basins in South China: implications for Rodinia break-up. Precambrian Research 122, 141-158.

ZHU, X., Sun, J., LI, Z. (2019) Iron isotopic variations of the Cryogenian banded iron formations: A new model. Precambrian Research 331, 105359. 